\title{
Quality of Randomized, Controlled Trials Published in Our National Journals
}

\author{
Ulusal Branş Dergilerimizde Basılan Randomize Kontrollü Çalışmaların Kalitesi
}

\author{
Salih ÖZGÖÇMEN \\ Department of Physical Medicine and Rehabilitation, Division of Rheumatology, \\ Erciyes University, Faculty of Medicine, Kayseri, Turkey
}

Turkish physiatrists have an increasing contribution to the scientific literature in the field of musculoskeletal medicine. In recent years, two well-known national journals initiated by Turkish physiatrists (The Turk J Physical Med Rehabil and Turk J Rheumatol) have been covered by leading abstracting/indexing databases such as Science Citation Index-Expanded, Scopus, EBSCO and EMBASE. This development has caused a marked increase in submissions both qualitatively and quantitatively. Randomized controlled trials (RCTs) are considered to be the "gold standard" for assessing the effectiveness of pharmacological and other interventions and also represent the best evidence in physiatry practice. ${ }^{[1,2]}$ Although the overall quality of RCTs reported in these journals have improved over time, reporting of key methodological issues still remains a problem. Herein, we would like to draw attention to the importance of the methodological quality of the randomized controlled trials published in the recent two years.

In 2009 and 2010, these journals published five uncontrolled interventional trials ${ }^{[3-7]}$ and 11 controlled trials. ${ }^{[8-19]}$ One of the major problems of the RCTs was the insufficient information regarding the method of randomization and allocation concealment. RCTs with an unclear generation of the allocation sequence, allocation concealment and double blinding frequently overestimate intervention efficacy. Another problem was insufficient information regarding sample size estimation and power analysis.

To conduct a systematic review and meta-analysis, searches are performed over the major databases such as Medline, Web of Science, etc. using the abstracts of the papers. Hence, it is essential to use terms like randomized, controlled, single- or double-blind, as well as prospective or placebo in the abstracts and titles of reports. The majority of the RCT reports in these journals miss these relevant terms as well as titles in their abstracts which increases the possibility of detecting them during the search procedure.

Authors need to pay closer attention to the rigorous implementation and reporting of important methodological safeguards against bias in randomized trials. To achieve this, investigators and editors developed the original CONSORT (Consolidated Standards of Reporting Trials) statement to alleviate the problems arising from inadequate reporting of randomized controlled trials (RCTs). The recent publication of the CONSORT 2010 Statement now makes the previous version, CONSORT 2001 Statement, outdated. All authors are strongly recommended to refer to this most up-to-date version while writing or interpreting reports of clinical trials. 


\section{Declaration of conflicting interests}

The author declared no conflicts of interest with respect to the authorship and/or publication of this article.

\section{Funding}

The author received no grant support for the research and authorship of this article.

\section{REFERENCES}

1. Moher D, Schulz KF, Altman DG. The CONSORT statement: revised recommendations for improving the quality of reports of parallel-group randomised trials. Lancet 2001;357:1191-4.

2. Prescott RJ, Counsell CE, Gillespie WJ, Grant AM, Russell IT, Kiauka S, et al. Factors that limit the quality, number and progress of randomised controlled trials. Health Technol Assess 1999;3:1-143.

3. Korkmaz N. Effects of pilates exercises on the social physical concern of patients with fibromyalgia syndrome: a pilot study. Turk J Rheumatol 2010;25:201-7.

4. Aktekin LA, Eser F, Bodur H, Tutoğlu A. Effect of oral to subcutaneous switch of methotrexate on disease activity in rheumatoid arthritis patients. Turk J Rheumatol 2009;24:140-3.

5. Akalan NE, Temelli Y, Kuchimov S. Effects of increased femoral anterversion on gait in children with cerebral palsy. Türk Fiz Tip Rehab Derg 2009;55:135-40.

6. Dilek B, Gülbahar S, Bacakoğlu K, Özkan M, Kızıl R, Akalın E. Rehabilitation outcomes after upper extremity replantation. Türk Fiz Tip Rehab Derg 2009;55:98-101.

7. Öz B, Bal S, Demirdöven C, Memiş A, Gürgan A, Şahin B, et al. Early rehabilitation outcome and demographic and clinical features of patients with traumatic tendon injury. Türk Fiz Tip Rehab Derg 2009;55:19-24.

8. Turhanoğlu AD, Güler $H$, İnanoğlu $\mathrm{D}$, İnanoğlu $\mathrm{K}$, Turhanoğlu S. Tramadol iontophoresis added to treatment of knee osteoarthritis. Turk J Rheumatol 2010;25:174-8.

9. Akyol Y, Durmuş D, Alaylı G, Tander B, Ulus Y, Cantürk F. Effectiveness of physical therapy agents in patients with lumbar spinal stenosis. Türk Fiz Tip Rehab Derg 2009;55:141-6.
10. Doğu B, Yilmaz F, Karan A, Ergöz E, Kuran B. Comparative the effectiveness of occlusal splint and TENS treatments on clinical findings and pain threshold of temporomandibular disorders secondary to bruxism. Türk Fiz Tip Rehab Derg 2009;55:1-7.

11. Koca B, Öz B, Ölmez N, Memiş A. Effect of lateralwedge shoe insoles on pain and function in patients with knee osteoarthritis. Türk Fiz Tip Rehab Derg 2009;55:158-62.

12. Külcü DG, Gülşen G. Effect of physical therapy program on insomnia severity in a patient population with fibromyalgia syndrome. Türk Fiz Tıp Rehab Derg 2009;55:64-7.

13. Külcü DG, Yanık B, Gülşen G, Gökmen D. Effect of neuromuscular electrical stimulation on pain and functional parameters in knee osteoarthritis. Türk Fiz Tip Rehab Derg 2009;55:111-5.

14. Umay E, Gürcay E, Çevikol A, Noyan S, Yüzer S, Çakçı A. Comparison of the outcomes of early versus late mobilization in rehabilitation following hand tendon injuries. Türk Fiz Tip Rehab Derg 2009;55:147-52.

15. Yılmaz F, Şahin F, Doğu B, Kuran B. Comparison of the effects of alendronate and calcitonin in postmenopausal osteoporosis. Türk Fiz Tip Rehab Derg 2009;55:102-6.

16. Evcik D, Kuru I, Ay S, Maralcan G. Home-based exercise and patellar bracig in the treatment of patellofemoral pain syndrome. Türk Fiz Tip Rehab Derg 2010;56:100-4.

17. Karapolat H, Gürgün A, Eyigör S, Ekren PK, Kirazlı Y. The effect of short-term pulmonary rehabilitation on pulmonary function tests, blood gases, functional capacity, dyspnea, quality of life and psychological symptoms in chronic pulmonary diseases: a retrospective study. Türk Fiz Tip Rehab Derg 2010;56:6-10.

18. Kitiş A, Kayıhan H. Comparison of EMG biofeedback and johnstone pressure splints in children with hemiplegic cerebral palsy. Türk Fiz Tip Rehab Derg 2010;56:116-123.

19. Güler $H$, Turhanoğlu AD, İnanoğlu $K$, İnanoğlu $D$, Özer C. Comparison of ketoprofen phonophoresis with ketoprofen and lidocaine-prilocaine phonophoresis in patients with subacromial impingement syndrome. Turk J Rheumatol 2009;24:88-93. 